ARQGA/1222

\title{
SHORT SEGMENT BARRETT'S ESOPHAGUS AND DISTAL GASTRIC INTESTINAL METAPLASIA
}

\author{
Judite DIETZ, Sílvia CHAVES-e-SILVA, Luíse MEURER, \\ Setsuo SEKINE, Andréa Ribeiro de SOUZA and Gilmara Coelho MEINE
}

ABSTRACT - Background - Short segment Barrett's esophagus is defined by the presence of $<3 \mathrm{~cm}$ of columnar-appearing mucosa in the distal esophagus with intestinal metaplasia on histophatological examination. Barrett's esophagus is a risk factor to develop adenocarcinoma of the esophagus. While Barrett's esophagus develops as a result of chronic gastroesophageal reflux disease, intestinal metaplasia in the gastric cardia is a consequence of chronic Helicobacter pylori infection and is associated with distal gastric intestinal metaplasia. It can be difficult to determine whether short-segment columnar epithelium with intestinal metaplasia are lining the esophagus (a condition called short segment Barrett's esophagus) or the proximal stomach (a condition called intestinal metaplasia of the gastric cardia). Aims - To study the association of short segment Barrett's esophagus (length $<3 \mathrm{~cm}$ ) with gastric intestinal metaplasia (antrum or body) and infection by $H$. pylori. Patients and methods - Eight-nine patients with short segment columnar-appearing mucosa in the esophagus, length $<3 \mathrm{~cm}$, were studied. Symptoms of gastroesophageal reflux disease were recorded. Biopsies were obtained immediately below the squamous-columnar lining, from gastric antrum and gastric corpus for investigation of intestinal metaplasia and $H$. pylori. Results - Forty-two from 89 (47.2\%) patients were diagnosed with esophageal intestinal metaplasia by histopathology. The mean-age was significantly higher in the group with esophageal intestinal metaplasia. The two groups were similar in terms of gender (male: female), gastroesophageal reflux disease symptoms and H. pylori infection. Gastric intestinal metaplasia (antrum or body) was diagnosed in 21 from $42(50.0 \%)$ patients in the group with esophageal intestinal metaplasia and 7 from 47 (14.9\%) patients in the group with esophageal columnar appearing mucosa but without intestinal metaplasia. Conclusion - Intestinal metaplasia is a frequent finding in patients with $<3 \mathrm{~cm}$ of columnar-appearing mucosa in the distal esophagus. In the present study, short segment intestinal metaplasia in the esophagus is associated with distal gastric intestinal metaplasia. Gastroesophageal reflux disease symptoms and $H$. pylori infection did not differ among the two groups studied.

HEADINGS - Barrett esophagus. Metaplasia. Helicobacter infections.

\section{INTRODUCTION}

Esophageal intestinal metaplasia is defined as a metaplastic change of the squamous epithelium of the distal esophagus into columnar epithelium containing goblets cells with any length ${ }^{(2,13,29,34)}$. Incomplete intestinal metaplasia or "specialized" columnar epithelium in the esophagus is the hallmark of Barrett's esophagus $(2,13,29,34)$. Intestinal metaplasia can be categorized according endoscopic and histological findings in long segment Barrett, short segment Barrett and intestinal metaplasia of $\operatorname{cardia}^{(3)}$. The yield of intestinal metaplasia from biopsies of columnar-type mucosa in the distal esophagus varies from $25 \%$ to $50 \%$ in short segment $(<3 \mathrm{~cm})$ to $80 \%$ in long segment Barrett's esophagus $(>3 \mathrm{~cm})^{(4,9,16)}$.

The most common predisposing factor to the development of Barrett's esophagus is chronic gastroesophageal reflux disease (GERD) ${ }^{(2,3)}$. This predisposing factor is really clear in Barrett's long segment; the pathogenesis of Barrett short segment and intestinal metaplasia of cardia is controversial $^{(21)}$. The condition develops when gastroesophageal reflux disease damages the squamous esophageal mucosa and the injury heals through a metaplastic process in which columnar cells replace squamous ones ${ }^{(2,22)}$. Barrett's esophagus is a risk factor for developing adenocarcinoma of the esophagus, although overestimated in the literature $\left({ }^{12,14,25)}\right.$. This is a tumor found predominantly in white men, among whom the frequency of esophageal adenocarcinoma has inexplicably quadrupled over the past few decades ${ }^{(6)}$.

While long segment Barrett's esophagus is a well defined entity and easily diagnosed, short segment Barrett's esophagus is less recognized, potentially being confused with intestinal metaplasia in the gastric cardia ${ }^{(30)}$. 
The precise determination of where the esophagus ends and the stomach begins is difficult endoscopically; the gastroesophageal junction cannot be identified with great precision, and the endoscopic measurements of the esophageal extent of columnar lining are imprecise $\mathrm{e}^{(26,30,31)}$. On the other hand, cardia intestinal metaplasia is an independent condition, a consequence of chronic Helicobacter pylori gastritis, being associated to distal gastric intestinal metaplasia ${ }^{(11,18)}$.

The objective of this study is to analyze the association of esophageal short-segment intestinal metaplasia with distal gastric intestinal metaplasia and infection by Helicobacter pylori.

\section{PATIENTS AND METHODS}

Patients 40 years or older undergoing upper gastrointestinal endoscopy for a diagnostic routine in a general hospital, from March 2002 to July 2003, were invited to participate. The study was approved by the Ethics Committee of the hospital in reference. Written informed consent was obtained from each patient. Patients were excluded if they had history of upper gastrointestinal bleeding, previous diagnosis of Barrett's esophagus, coagulopathy, esophageal varices, esophagitis, upper gastrointestinal neoplasms, previous gastroesophageal surgery, or severe co-morbidity. Before endoscopy, the patients were questioned about symptoms of gastroesophageal reflux. Diagnostic criteria of GERD were symptoms such as heartburn and/or regurgitation at least once a week for the last 6 months. Upper endoscopy was performed with an Olympus video GIF-145. Endoscopically, the junction between the esophagus and the stomach was identified at the level of the proximal gastric folds. Normally, the squamous-columnar line and the gastroesophageal junction coincide, with no finger-like upward projections. Patients with columnar appearing mucosa in the distal esophagus with extension $<3 \mathrm{~cm}$ were included. The cases of squamous-columnar line which coincide with, or are $1 \mathrm{~cm}$ above, the gastroesophageal junction were not included. Four biopsy specimens were obtained immediately below the squamous-columnar line.

All biopsy specimens were stained with hematoxylin-eosin and Alcian blue $\mathrm{pH}$ 2.5. The diagnosis of intestinal metaplasia was confirmed by the presence of goblets cells in the biopsy specimens obtained from the columnar-appearing mucosa from distal esophagus. Two fragments of gastric antrum and two from gastric corpus, stained with hematoxylin-eosin and Giemsa, were carried out for the histopathological examination of intestinal metaplasia and infection by Helicobacter pylori. For statistical analysis the chi-squared test were used to compare discontinuous data. $T$ test was calculated for continuous variables. $P$-values $<0.05$ were considered significant. For determining the relative contributions of independent variables to predict esophageal intestinal metaplasia, we performed a logistic regression.

\section{RESULTS}

A total of 89 consecutive patients with an endoscopic diagnosis of columnar-appearing mucosa with less than $3 \mathrm{~cm}$ extension in the distal esophagus were studied. Among the 89 patients, $42(47.2 \%)$ had intestinal metaplasia in the distal esophagus by histopathologic exam. The 42 patients with short segment intestinal metaplasia in the distal esophagus had higher mean age as compared with the 47 patients without evidence of esophageal intestinal metaplasia (Table 1). The two groups did not differ statistically regarding the variables gender, GERD symptoms, Helicobacter pylori infection (Table 1). The presence of intestinal metaplasia in the gastric body or antrum was statistically significant in the group with intestinal metaplasia in the distal esophagus (Table 1).

TABLE 1 - Age, male gender, GERD symptoms, Helicobacter pylori infection and distal gastric intestinal metaplasia in patients with and without short segment intestinal metaplasia in the distal esophagus (length $<3 \mathrm{~cm}$ )

\begin{tabular}{lcccc}
\hline Variables & $\begin{array}{c}\text { Esophageal } \\
\text { intestinal } \\
\text { metaplasia } \\
(\mathbf{n}=42)\end{array}$ & $\begin{array}{c}\text { Esophageal columnar } \\
\text { epithelium without } \\
\text { intestinal metaplasia } \\
(\mathbf{n}=47)\end{array}$ & OR (CI95\%) & $\boldsymbol{P}$ \\
\hline Age & 63.2 & 56.3 & $2.87(1.14 ; 7.24)$ & 0.004 \\
Male & $18(42.9)$ & $21(44.7)$ & $0.93(0.40 ; 2.15)$ & 1.000 \\
GERD symptoms & $23(57.5)$ & $30(68.2)$ & $0.63(0.26 ; 1.54)$ & 0.369 \\
$\begin{array}{l}\text { Helicobacter pylori } \\
\text { infection }\end{array}$ & $29(70.7)$ & $27(57.4)$ & $1.79(0.74 ; 4.35)$ & 0.267 \\
$\begin{array}{l}\text { Corpus/antrum } \\
\text { gastric intestinal } \\
\text { metaplasia * }\end{array}$ & $21(50.0)$ & $7(14.9)$ & & \\
\hline
\end{tabular}

* Variables presented as frequency (percentage).

Statistically significant differences at the 0.05 level of significance.

\section{DISCUSSION}

Esophageal adenocarcinoma develops in approximately $0.5 \%$ of patients with Barrett's esophagus per year ${ }^{(25)}$. The major risk factor is Barrett's esophagus, with $64 \%-86 \%$ of all esophageal adenocarcinomas originating in metaplastic columnar epithelium ${ }^{(1,12,14)}$. The prerequisite for the diagnosis of Barrett's esophagus is the presence of intestinal-type goblet cells in the lower esophagus ${ }^{(34)}$. Patients with Barrett's esophagus should undergo regular endoscopic surveillance for early detection of curable neoplasia in order to decrease the risk of death from esophageal cancer ${ }^{(7,23)}$. Esophageal intestinal metaplasia develops as a sequela of chronic GERD, whereas intestinal metaplasia in the stomach, including cardia, is a consequence of chronic Helicobacter pylori infection ${ }^{(5)}$.

It can be difficult to determine the difference between short segments of columnar epithelium with intestinal metaplasia lining the distal esophagus (a condition called short segment Barrett's esophagus) from the columnar epithelium with intestinal metaplasia present in the proximal stomach (a condition called gastric cardia intestinal metaplasia $)^{(26,28)}$. On the other hand, no clear definition of normal Z-line exists and even the normal esophagus could be lined by $2 \mathrm{~cm}$ of columnar epithelium ${ }^{(15,33)}$. Endoscopically, the gastric folds that delimit the stomach are dynamic structures whose proximal extent may vary with respiration and gagging, and with the degree of gastric distention ${ }^{(31)}$. 
Even in a specialized gastroenterology setting, reproducibility of presumptive endoscopic or histological diagnoses of Barrett's esophagus at follow-up were poor ${ }^{(17)}$. Only $10 \%-20 \%$ of cases with either endoscopic or histological suspicion of Barrett's esophagus had establish Barrett's esophagus after 2,5 years of follow-up ${ }^{(17)}$.

The role of intestinal metaplasia as a premalignant lesion of the cardia has not yet been established ${ }^{(27)}$. Additionally the prevalence of cardia dysplasia is very low ${ }^{(18,27)}$. Cardia intestinal metaplasia is associated with gastric distal intestinal metaplasia and with Helicobacter pylori infection ${ }^{(8,10,18)}$. Association of esophageal intestinal metaplasia (short segment), with gastric distal intestinal metaplasia was reported in the literature ${ }^{(32,35)}$.

Cytokeratins CK7 and CK20 expression pattern analysis discriminates correctly between intestinal metaplasia in Barrett's esophagus and intestinal metaplasia of the cardia in the majority of cases ${ }^{(19,20,24)}$. However, immunohistochemical investigations could not improve the diagnostic accuracy of hematoxylin and eosin histology alone ${ }^{(19,20,24)}$.

In our study, patients with esophageal intestinal metaplasia (short segment) did not differ statistically from patients with $<3 \mathrm{~cm}$ columnar-appearing mucosa in the distal esophagus without histopathologic evidence of intestinal metaplasia, regarding male gender, GERD symptoms, and Helicobacter pylori infection. However, patients with intestinal metaplasia in the distal esophagus had a higher mean age and higher association with gastric intestinal metaplasia in the body and antrum.

\section{CONCLUSION}

This study shows that short segment intestinal metaplasia of the distal esophagus presented similar previously described characteristics as intestinal metaplasia of the cardia finding in the literature. These findings could result from the lack of precise anatomic delimitation between gastro-esophageal junction and cardia and as a consequence overlap between the definition of short segment Barrett's esophagus and intestinal metaplasia of the cardia. The absence of objective distinction may interfere in the management of patients with esophageal intestinal metaplasia, short segment $(<3 \mathrm{~cm})$. The importance in this distinction (esophageal or cardia intestinal metaplasia) will be the different prognostic implications for early diagnosis of displasias and potentially the development of esophageal adenocarcinoma.

Dietz J, Chaves e Silva S, Meurer L, Sekine S, Souza AR, Meine GC. Esôfago de Barrett de segmento curto e metaplasia intestinal gástrica distal. Arq Gastroenterol. 2006;43(2):117-20.

RESUMO - Racional - Esôfago de Barrett de segmento curto é definido pela presença de mucosa semelhante à gástrica no esôfago distal, extensão $<3 \mathrm{~cm}$, com metaplasia intestinal na histopatologia. Esôfago de Barrett é fator de risco ao adenocarcinoma do esôfago. Enquanto esôfago de Barrett se desenvolve como resultado do refluxo gastroesofágico crônico, metaplasia intestinal da cárdia é conseqüência da infecção crônica pelo Helicobacter pylori e está associada à metaplasia gástrica distal. Epitélio colunar com metaplasia intestinal localizada no esôfago distal, extensão $<3 \mathrm{~cm}$ (condição denominada de esôfago de Barrett de segmento curto) ou a mesma entidade localizada no estômago proximal (condição denominada de metaplasia intestinal da cárdia) por ser muitas vezes confundida. Objetivo - Estudar a associação de esôfago de Barrett segmento curto (extensão $<3 \mathrm{~cm}$ ) com metaplasia intestinal gástrica (corpo e antro) e infecção pelo Helicobacter pylori. Pacientes e métodos - Participaram do estudo 89 pacientes com mucosa do esôfago distal semelhante à gástrica, extensão $<3 \mathrm{~cm}$. Os pacientes foram questionados sobre sintomas de doença do refluxo gastroesofágico. Biopsias foram obtidas imediatamente abaixo da transição escamocolunar e do corpo e antro gástrico para investigação de metaplasia intestinal e pesquisa de Helicobacter pylori. Resultados - Quarenta e dois dos $89(47,2 \%)$ pacientes foram diagnosticados com metaplasia intestinal esofágica na histopatologia. A idade média foi significativamente mais alta no grupo com metaplasia intestinal esofágica. Nos dois grupos estudados (com e sem metaplasia intestinal de esôfago distal), a relação masculino/feminino, sintomas de doença do refluxo gastroesofágico e infecção pelo Helicobacter pylori foi semelhante. Metaplasia intestinal gástrica (corpo e antro) foi diagnosticada em 21 de 42 (50,0\%) dos pacientes com metaplasia intestinal esofágica e 7 de 47 (14,9\%) do grupo com mucosa colunar esofágica, mas sem evidência de metaplasia intestinal. Conclusão - Metaplasia intestinal é achado freqüente em pacientes com mucosa semelhante à gástrica no esôfago distal, extensão $<3 \mathrm{~cm}$. No presente estudo, metaplasia intestinal de segmento curto no esôfago está associada à metaplasia gástrica distal. A freqüência de sintomas de refluxo gastroesofágico e infecção pelo Helicobacter pylori não mostrou diferenças significativas nos dois grupos estudados

DESCRITORES - Esôfago de Barrett. Metaplasia. Infecções por helicobacter. 


\section{REFERENCES}

1. Blot WJ, Devesa SS, Kneller RW, Fraumeni JF. Rising incidence of adenocarcinoma of the esophagus and gastric cardia. JAMA 1991;265:1287-9.

2. Cameron AJ. Epidemiology of Barrett's esophagus. Gastroenterol Clin Biol. 1994;18 D3-D4.

3. Caum LC, Bizinelli SL, Pisani JC, Amarantes HM, Ioshii SO, Carmes ER. Metaplasia intestinal especializada de esôfago distal na doença do refluxo gastroesofágico: prevalência e aspectos clínico-epidemiológicos. Arq Gastroenterol. 2003;40:220-6.

4. Chalasani N, Wo JM, Hunter JG, Waring JP. Significance of ntestinal metaplasia in different areas of esophagus including esophagogastric junction. Dig Dis Sci. 1997;42:603-7.

5. Correa P. Helicobacter pylori and gastric carcinogesis. Am J Surg Pathol. 1995;19(Suppl 1):s37-s43.

6. Devesa S, Blot WF, Fraumeni JF. Changing patterns in the incidence of esophageal and gastric carcinoma in the United States. Cancer. 1998;83:2049-53.

7. Eckardt VF, Kanzler G, Bernhard G. Life expectance and cancer risk in patient with Barrett's esophagus: a prospective controlled investigation. Am J Gastroenterol. 2001;111:33-7.

8. El-Serag HB, Sonnenberg A, Jamal MM, Kinkel D, Crooks L, Feddersen RM. Characteristics of intestinal metaplasia in the gastric cardia. Am J Gastroenterol. 1999;94:622-7.

9. Eloubeidi MA; Provenzale D. Does this patient have Barrett's esophagus? The utility of predicting Barrett's esophagus at the index endoscopy. Am J Gastroenterol. 1999;94:937-43.

10. Goldblum JR, Vicari JJ, Falk GW, Rice TW, Peek RM, Easley K, Richter JE. Inflammation and intestinal metaplasia of the gastric cardia: the role of gastroesophageal reflux and H. pylori infection. Gastroenterology. 1998;114:633-9.

11. Goldblum JR, Richter JE, Vaezi M, Falk GW, Rice TW, Peek RM. Helicobacter pylor infection, not gastroesophageal reflux, is the major cause of inflammation and intestinal metaplasia of gastric cardiac mucosa. Am J Gastroenterol. 2002;97:302-11.

12. Haggitt RC, Tryzelaar J, Ellis FH, Colcher H. Adenocarcinoma complicating columnar epithelium-lined (Barrett's) esophagus. Am J Clin Pathol. 1978;70:1-5.

13. Haggitt RC. Barrett's esophagus, dysplasia and adenocarcinoma. Hum Pathol. 1994;25:982-3.

14. Hamilton SR, Smith RRL, Cameron JL. Prevalence and characteristics of Barrett esophagus in patients with adenocarcinoma of the esophagus or esophagogastric junction. Hum Pathol. 1988;19:942-8.

15. Hayward J. The lower end of the oesophagus. Thorax. 1961;16:36-41.

16. Johnston MH, Hammond AS, Laskin W, Jones DM. The prevalence and clinical characteristics of short segments of specialized intestinal metaplasia in the distal esophagus on routine endoscopy. Am J Gastroenterol. 1996;91:1507-11.

17. Meining A, Ott R, Becker I, Hahn S, Muhlen J, Werner M, Hofler H, Classen M, Helwein W, Rosch T. The Munich Barrett follow-up study: suspicion of Barrett's esophagus based on either endoscopy or histology only - what is the clinical significance? Gut. 2004;53:1402-7.

18. Morales TG, Sampliner RE, Bhattacharyya A. Intestinal metaplasia of the gastric cardia. Am J Gastroenterol. 1997;92:414-8.
19. Ormsby AH, Goldblum JR, Rice TW, Richter JE, Falk GW, Vaezi MF, Gramlich TL. Cytoqueratin subsets can reliably distinguish Barrett's esophagus from intestinal metaplasia of the stomach. Hum Pathol. 1999;30:288-94.

20. Ormsby AH, Vaezi MF, Richter JE, Goldblum JR, Rice TW, Falk GW, Gramlich TL. Cytokeratin immunoreactivity patterns in the diagnosis of short-segment Barrett's esophagus. Gastroenterology. 2000;119:683-90.

21. Pera M. Trends in incidence and prevalence of specialized intestinal metaplasia, Barrett's esophagus and adenocarcinoma of the gastroesophageal junction. World $\mathrm{J}$ Surg. 2003;27:999-1008.

22. Riddell RH. The genesis of Barrett esophagus: has a histologic transition from gastroesophageal reflux disease-damaged epithelium to columnar metaplasia ever been seen in humans? Arch Pathol Lab Med. 2005;129:164-9.

23. Sampliner RE. Practice guidelines on the diagnosis, surveillance, and therapy of Barrett's esophagus. The Practice Parameters Committee of the American College of Gastroenterology. Am J Gastroenterol. 1998;93:1028-32.

24. Sarbia M, Donner A, Franke C, Gabbert HE. Distintion between intestinal metaplasia in the cardia and in Barrett's esophagus: the role of histology and immunohistochemistry. Hum Pathol. 2004;35:371-7.

25. Shaheen NJ, Crosby MA, Bozymski EM, Sandler RS. Is there publication bias in the reporting of cancer risk in Barrett's esophagus? Gastroenterology. 2000;119:333-8

26. Sharma P, Morales TG, Sampliner RE. Short segment Barrett's esophagus - the need for standardization of the definition and of endoscopic criteria. Am J Gastroenterol. 1998;93:1033-6.

27. Sharma P, Weston AP, Morales T, Topalovski M, Mayo MS, Sampliner RE. Relative risk of dysplasia for patients with intestinal metaplasia in the distal oesophagus and in the gastric cardia. Gut. 2000;46:9-13.

28. Sharma P. Short segment Barrett esophagus and specialized columnar mucosa at the gastroesophageal junction. Mayo Clin Proc. 2001;76:331-4.

29. Spechler SJ. Short and Ultrashort Barrett's Esophagus - What does it mean? Sem Gastrointest Dis. 1997;8:59-67.

30. Spechler SJ. Barrett's esophagus. N Engl J Med. 2002;346:836-42.

31. Spechler SJ. Intestinal metaplasia at the gastroesophageal junction. Gastroenterology. 2004; $126: 567-75$

32. Trudgill NJ, Suvarna SK, Kapur KC, Riley AS. Intestinal metaplasia at the squamocolumnar junction in patients attending for diagnostic gastroscopy. Gut. 1997;41:585-9.

33. Wallner B, Sylvan A, Stenling R, Janunger KG. The esophageal Z-line appearance correlates to the prevalence of intestinal metaplasia. Scand J Gastroenterol. 2000;35:17-22.

34. Weinstein WM, Ippoliti AF. The diagnosis of Barrett's esophagus: goblets, goblets, goblets. Gastrointest Endosc. 1996;44:91-5.

35. Weston AP, Krmpotich P, Makdisi WF, Cherian R, Dixon A, McGregor DH, Banerjee SK. Short segment Barrett's esophagus: clinical and histological features, associated endoscopic findings and association with gastric intestinal metaplasia. Am J Gastroenterol. 1996;91:981-6. 